\title{
ASSESSMENT OF THE PERCEIVED IMPACT OF HOME INFORMATION AND COMMUNICATION TECHNOLOGY ON PUPILS' SOCIAL SKILLS DEVELOPMENT
}

\section{EMMANUEL C. OKENYI ${ }^{1}$, ANTHONIA N. NGWOKE ${ }^{2 *}$, VICTOR S. EZEMA ${ }^{3}$, ANTHONIA O.} ANEKE $^{4}$; HILARY E. ASOGWA ${ }^{5}$ \& CHRISTIAN S. UGWUANYI ${ }^{6,7}$

${ }^{1,2,3,4}$ Department of Educational Foundations, Faculty of Education, University of Nigeria, Nsukka

${ }^{5}$ School of Language, Department of English Language, Federal College of Education, Eha-Amufu

${ }^{6}$ School of Education Studies, Faculty of Education, University of the Free State, Bloemfontein, 9300, South Africa

${ }^{7}$ Department of Science Education, Faculty of Education, University of Nigeria, Nsukka

ABSTRACT
The study investigated the perceived influence of home information and communication technology (ICT) on
the social skills development of primary school children in Igbo-Etiti Local Government Education Authority,
Enugu State, Nigeria. The study adopted a descriptive survey research design. The population of the study
comprised 1,803 primary five pupils in the 62 public primary schools in Igbo-Etiti Local Government
Education Authority, Enugu State. A sample of 317 primary 5 pupils drawn through simple random sampling
technique was used for the study. The instrument used for data collection was a Perceived Impact of Home
ICT on Social Skills Development Questionnaire. The reliability of the instrument was determined through a
preliminary survey in Udenu Local Government Education Authority, Enugu State. Using Cronbach Alpha
reliability estimate, reliability indices of 0.84 and 0.75 were obtained for the two clusters of the instrument.
Mean and standard deviation were used to answer the research questions. The null hypothesis was tested using
t-test statistic at 0.05 level of significance. The results showed that majority of the pupils do not have access to
home ICT. The findings also revealed that home ICT has positive impact on pupils'social skill development.
Based on the findings, it was recommended among others that provision for easy access to home ICT should
be made by the Local Government Education Authority to enable the pupils develop their social skills.
KEYWORDS: Home ICT, Perceived impact, Pupils, Social Skills Development

Received: Dec 08, 2020; Accepted: Dec 28, 2020; Published: Jan 20, 2021; Paper Id.: IJMPERDFEB20216

\section{INTRODUCTION}

Universally, children are seen as the pride and future hope of the nations and human race in general. To this end responsible and responsive families and governments sacrifice and invest immensely on the development and education of the children. Scholars maintain that the quality of a nation's development reflects the quality of life skills acquired by the children as young citizens of the nation (Culliance \& Montacute, 2017).

A child ordinarily refers to a person who is still under the guidance, care, and protection of parents or other adults for survival and proper growth and development. The United Nations defined a child as a person below the age of 18 and incapable of reason. Similarly, Renuka (2018) stated that a child is any person under the 
age of 18 or a person incapable of giving consent to certain actions. Therefore, a child is a person between the ages of 0 and 18 years, who is still under the care of more knowledgeable others such as parents, guardians, caregivers, and teachers. This means that a child is a person who is dependent on others for his or her wellbeing. Children are born into families where they are nurtured before transiting to school and eventually into the society.

The family is the basic unit of the society and the closest associate of the child. According to Harper (n.d) the family is seen as a group of individuals united either by consanguinity or affinity and is made up of parents and children. This is to say that the child starts his journey of life and development under the parents. It is on this note that Social Mettle (2018) stated that in the developmental process of the child, the child learns first to interpret and understand himself and his environment through the feelings of his parents and other members of the family. This implies that the parents are the leaders and managers of the family and take the responsibility of socializing the child from the cradle. This is the case in a biological parent. Bedford Borough Council (2018) also defined parent to include any person who may through the law of adoption or otherwise exercise parental responsibility for a young person. In the context of this study, a parent is the one who has the legal, social and moral responsibility for a child's growth and development and wellbeing. Parents are the primary caregivers, protectors and educators of young children, that equips the child with elementary skills for life in the wider society.

Apparently, every society needs skilled and educated citizenry for survival and development. Education is a process of refining the intellect and innate skills of an individual. Education is a veritable tool to achieving a society's developmental goals. Given a well-planned education system, all categories of manpower need of the community are provided. Onuselogu Onuselogu (2007) described education as a means of enlightenment and a process of training and preparation for useful life in the community. The Federal Republic of Nigeria (FRN) Federal Republic of Nigeria (2013) referred to education as a vital instrument to be employed for national development. Therefore, the formulation of ideas, their integration for national development and the interaction of persons and ideas are all aspects of education. Education may be referred to as a social good. According to Roji (2004), education is both social and private good that is capable of yielding benefits for the future. It is in this light that Okenyi, Ugwuanyi and Ugwu (2018), stated that education as a social good is expected to be a civic right of every Nigerian child. Education provides the framework for preparing the young members of the society socially, intellectually and morally so as to function effectively in the society.

Nations focus on education as an instrument for human development and nation building. Echoing this opinion, Chukwu (2011) maintained that education is a process of assisting the leaners to acquire knowledge, values, skills and acceptable attitude and morals that would make them responsible citizens and in effect, enable them care for themselves and their families, and contribute meaningfully to society's development. Education is therefore, a means of integrating the individual into the wider society in which he is born. By implication education is the process of training and developing the mental potentials, physical knowledge, skill and different character of individuals by formal and informal schooling. The appropriate place for the education of the child is the primary school. In Nigeria, the first step of formal schooling is formal education.

Primary education is a structured programme designed to provide teaching and learning environment for children. Primary school is an educational institution that provide educational instruction to children aged 5 and 11 plus who are referred to Collins (2020). Primary schools place a major emphasis on teaching children the basic skills of reading, writing, language and Mathematics. The arts, languages other than English, social education programs, health and physical 
recreation also play important roles in primary education programs (Okenyi, Ugwuanyi \& Ugwu, 2018; Education and Training Directorate, 2015). In the process of educating the child, ICT and home computers seem to have become popular and unavoidable tool in the contemporary society. A modern child is born into technology and a digital world in which he is developing a varied array of knowledge, skills and understanding (Nikolopoulou \& Gialmas, 2010). According to Wartella, Vandewater and Rideout (2006), the issue of ICT ownership now incorporates home ownership in households that contain children and its impact on children.

Information and Communication Technology (ICT) refers to the manipulation of information through the use of electronic technology. It is a system that involves network management through the use of computers. According to Alberta (2019), ICT refers to systems or technologies employed to manipulate telecommunications, intelligent building management systems, broadcast media among others. This implies that ICT has to do with internet and other wireless networks. Ratheeswari (2018) described ICT as a form of technology that provide access to processed data by means of broadcastings. ICT is similar to Information Technology (IT) but concentrates more on communication mechanisms which include but not limited to wireless networks, cell phones, home computers and other communication gadgets. The most available means through which pupils access ICTs is through the home computer. For Joseph (2017) ICT is made available in the homes through home computers such as desktops, laptops, chrome book, windows tablets among others. Young children of school age are given access to such computers as learning resource, to watch cartoons, play computer games among others. According to Subrahmanyam et al. (2000), the industrial revolution has boosted the availability of home computers and has increased the role of home computers and ICT in children's lives and as such time spent on home computers may displace other activities that may impact more value on the children's development. ICT therefor, refers to a set of diverse technological devices and reserves utilized to create and process data, communicate and disseminate information, store and manage information. However, according to Ryan \& Lewis (2017), ICT has become increasingly indispensable in the day to day lives of the people including children. Ryan and Lewis went further to emphasize the importance of ICT in taking classes and in individual development as well as economic growth.

The benefits of ICT seem enormous in the area of child development. According to Olowe and Kukelu (2014), ICT can facilitate all round development of children, social-emotional development inclusive. This underscores the importance of ICT for the pupils. Confirming this stance, Tagarira (2017) insisted that ICT can aid pupils in fine motor skills, gross motor skills, creative, social skills and emotional developments among others. Despite the importance of ICT in child development, the extent to which ICT is accessible to school age children in Nigeria seems unclear. Also, Tella (2011) maintained that even where there is the availability of computers and other ICT resources in schools and homes, there is still low usage of these facilities by the pupils and students as accessibility to these facilities are limited. UKessays (2018) countered this point of view by stating categorically that over $60 \%$ of Nigerian populace lives in rural areas and has no access to social amenities such as computers with IT facilities for information distribution. Ukessays further observed that males seem to benefit more from ICT resources than females.

In terms of gender and benefits, if seems ICT is not gender sensitive in the sense that both male and female pupils are equally interested and use home ICT. Tondeur, Sinnaeve, van Houtte and van Braal (2011) insinuated that gender has no impact in the use of computers and ICTs for educational purposes. Buttressing this point, Naciri (2014) stated that though male and female children have equal opportunity in terms of access, use and impact of ICT there seem to be a difference between them in terms of attitude and patterns of use. These imply that both gender access and use ICT equally 
but usage pattern and attitudes differ. Buttressing this point, Bakola, Rizos and Drigas (2019), stated that ICT is beneficial for the social skills development of children even those with Attention Deficit Hyperactivity Disorder (ADHD) and Autism Spectrum Disorder (ASD) irrespective of age and gender. Access is a critical issue for children to benefit from ICT resources. It is only when children have access to ICT that they can utilize it and benefit from it. In Igbo-Etiti, the degree of access to ICT by pupils is indeterminable. This is because many of the communities lack basic social amenities that support ICT utilization and one cannot clearly visualize the possibilities of individual families providing such amenities on their own. Without adequate access and utilization of ICT, pupils' social skill development may be hampered.

Social skills encompass the skills needed for healthy interpersonal relationship. Social skill development therefore, is a critical aspect of child development. According to Reflection Sciences (2017), social skill development remains a vital aspects of a child's overall health, well-being, and happiness; and they are linked to cognitive and emotional development. Social skill development is a process of acquiring and imbibing ways and healthy means of communication and interaction with others (Mazarin, 2020). It is the process through which the child's social behaviours and interactions are shaped to concur with the standard social norms. SkillsYouNeed.com (2020) insists that social skill development is making the child aware of how to communicate with others, improving the method of communication to make the child communicate in more efficient and effective ways. Social skills are very important for a successful life in the society. SkillsYouNeed.com maintains that well developed social skills enhance quality and lasting relationships which in turn reduces the negative impacts of stress and enhances one's self-esteem. The child's social skill development is shaped and directed by parents as the first teachers of the child (Nvgvist \& Engvall, 200). Through constant and consistent interaction with parents and other adult members of the family a child's social skills are adequately developed. The availability and access to home ICT seem to compliment these desired interactions with the adult members of the family. In Nigeria, there is scarcity of studies that investigated the impact of ICT on school children. To this effect, the preoccupation of this study is to examine the perceived impact of home computer on primary school children.

\section{Statement of the Problem}

The rate of prevalence of ICT resources for children and adults in the contemporary society is unimaginable. ICT resources are also increasingly penetrating classroom interactions at all levels of education especially pre-primary and primary schools. Developmentally appropriate ICT engenders social skills development in young children by providing opportunities for them to interact with people and objects outside their immediate environment. The home which is the primary socializing agents for the child need to be aligned with the current trend of technological advancement, so that children are better prepared socially early enough for technology assisted learning in school and meaningful learning in a technology driven world. Unfortunately, in Nigeria, especially in Igbo-Etiti LGEA, the degree of access to ICT that pupils have at home is not clear. This may be partly due to lack of social amenities that support proper adoption of ICT such as power supply. Also, it is not clear how many families that can provide such facilities on their own. In such circumstances, pupils may not have proper perception of how ICT can influence their social skills development; and a child without sound social background after primary school may end up in role confusion at adolescence. On the basis of this, the problem of this study put in question form is: what is the impact of ICT in social skills development as perceived by pupils?

The general purpose of the study was to investigate the impact of home computer on development of school children. Specifically, the study sought to determine:

- How primary school pupils have access to home ICT in Igbo-Etiti Local Government Education Authority. 
- The perceived impact of home ICT on social skill development of pupils in Igbo-Etiti Local Government Education Authority.

\section{Research Questions}

The study was guided by two research questions:

- How do pupils have access to home ICT in Igbo-Etiti Local Government Education Authority?

- What is the perceived impact of home ICT on the social skill development of pupils?

\section{Hypotheses}

Ho: There is no significant difference in the mean ratings of male and female pupils on the perceived impact of home ICT on their social skill development.

\section{METHODS}

\section{ETHICAL CONSIDERATIONS}

Research Ethics Committee of the Faculty of Education, University of Nigeria approved this study. Students who participated in this study provided informed assent. The participants were severed informed consent forms to fill and sign before the sampling procedure.

\section{DESIGN OF THE STUDY}

The study adopted a descriptive survey research design. Descriptive survey research design guides a study which intention is to determine the attributes of a given population using a sample of the population. The results of such study are generalised to the entire population.

\section{PARTICIPANTS}

The population of the study comprised all the 1,803 primary (5) five pupils in the entire 62 public primary schools in IgboEtiti Local Government Education Authority, Enugu state, Nigeria (Source: Office of the Secretary, Igbo-Etit Local Government Education Authority, Enugu state). A sample size of 317 primary 5 pupils (146 males and 171 female pupils) obtained through Simple random sampling technique was used for the study. The sample size was arrived at using Taro Yamane formula.

\section{MEASURE AND DATA COLLECTION PROCEDURE}

A structured questionnaire titled Perceived Impact of Home ICT on Social Skill Development Questionnaire was used for data collection. The instrument was a 30-item questionnaire with two clusters A \& B. Cluster A had 14 items and sought information on the children's access to home ICT with response options as; very often (4); often (3); rarely (2); never (1). Cluster B had 16 items and sought information on the influence of home ICT on their social skills development as perceived by pupils with four points response options of: Strongly Agree (4); Agree (3); Disagree (2); and Strongly Disagree (1).

The instrument was validated by three (3) experts; one each from Childhood Education unit and Educational Psychology unit, Department of Educational Foundations, and one from Measurement and Evaluation Unit, Department of Science Education all of Faculty of Education, university of Nigeria, Nsukka (UNN). Their corrections and 
Emmanuel C. Okenyi, Anthonia N. Ngwoke*, Victor S. Ezema, Anthonia O. Aneke, Hilary E. Asogwa ${ }^{5}$ \& Christian S. Ugwuanyi

recommendations were effected and incorporated into the instrument. The reliability of the instrument was determined through pilot-testing carried out with 10 primary five (5) pupils in Nsukka Local Government Education Authority. The reliability of the instrument was determined through pilot-testing carried out with 30 primary five pupils (5) pupils in Nsukka Local Government Education Authority, using Cronbach Alpha formula, internal consistency reliability indices of 0.84 and 0.75 were obtained for clusters A and B respectively. The instrument was administered with the help of two research assistants who were instructed by the researchers. The instrument was administered and retrieved on the spot.

\section{DATA ANALYSIS}

Data collected were analyzed using mean and standard deviation to answer the research questions and t-test of independent samples to test the null hypothesis at 0.05 level of significance.

\section{RESULTS}

Research Question One: How do pupils have access to home ICT in Igbo-Etiti Local Government Education Authority?

Table 1: Frequency and mean analysis of the pupils' ratings of their access to home ICT

\begin{tabular}{|c|l|c|c|c|c|c|c|c|}
\hline S/no & Access to Home ICT & Alone & $\begin{array}{c}\text { Needs } \\
\text { help }\end{array}$ & $\begin{array}{c}\text { With } \\
\text { siblings }\end{array}$ & $\begin{array}{c}\text { With } \\
\text { adult }\end{array}$ & Never & Mean & Remarks \\
\hline 1 & TV & 36 & 35 & 36 & 66 & 144 & 2.22 & WA \\
\hline 2 & Toys-robots & 1 & 35 & 36 & 66 & 179 & 1.77 & WA \\
\hline 3 & DVD & 1 & 0 & 36 & 101 & 179 & 1.55 & WA \\
\hline 4 & Mus. Keyboard & 1 & 0 & 1 & 2 & 313 & 1.11 & N \\
\hline 5 & CD/tape player and disc & 3 & 30 & 36 & 66 & 155 & 1.74 & $\mathrm{~N}$ \\
\hline 6 & Handheld electric games & 0 & 0 & 0 & 2 & 315 & 1.10 & $\mathrm{~N}$ \\
\hline 7 & Game console & 2 & 1 & 3 & 10 & 301 & 1.15 & $\mathrm{~N}$ \\
\hline 8 & Education software & 1 & 4 & 7 & 26 & 279 & 1.44 & $\mathrm{~N}$ \\
\hline 9 & Digital camera & 0 & 0 & 0 & 8 & 299 & 1.13 & $\mathrm{~N}$ \\
\hline 10 & MS Office & 10 & 12 & 9 & 12 & 274 & 1.54 & $\mathrm{WA}$ \\
\hline 11 & Computer & 10 & 12 & 9 & 12 & 274 & 1.54 & WA \\
\hline 12 & Printer & 0 & 0 & 0 & 7 & 300 & 1.02 & $\mathrm{~N}$ \\
\hline 13 & Video Camera & 0 & 0 & 0 & 7 & 300 & 1.02 & $\mathrm{~N}$ \\
\hline 14 & Internet & 0 & 0 & 0 & 15 & 302 & 1.04 & $\mathrm{~N}$ \\
& & & & & & & \\
\hline & Overall Mean Access & & & & & & $\mathbf{2 0 . 4 0}$ & N \\
\hline
\end{tabular}

\section{WA $=$ With Adult,$\quad N=$ Never}

Table 1 shows the frequency as well the mean ratings of the pupils on how they have access to home ICT. It shows that majority of the people never accessed ICT at home. Table 1 further shows that the pupils through adults have access items $1,2,3,5,10$, and 11 , but never had access to items $4,6,7,8,9,12,13$ and 14 . Besides, the overall mean rating of 20.40 out of a maximum mean of 70.00 showed that pupils never had access home ICT.

Research Question Two: What is the perceived impact of home ICT on the social skill development of pupils?

Table 2: Mean analysis of the pupils' ratings on perceived impact of home ICT on their social skill development

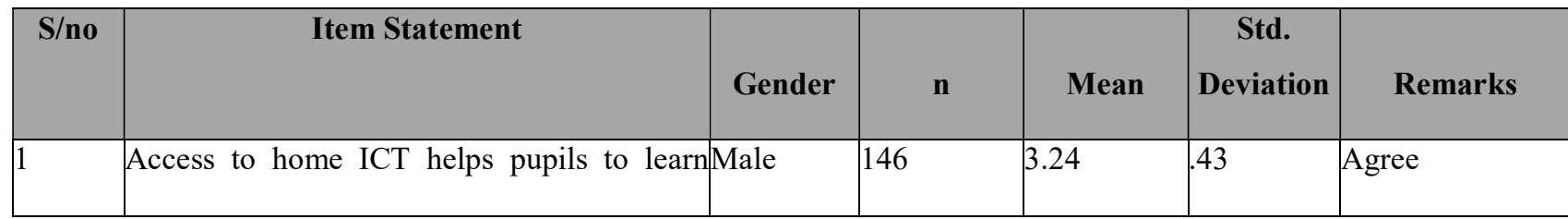


Technology on Pupils' Social Skills Development

\begin{tabular}{|c|c|c|c|c|c|c|}
\hline & how to take care of the environment & Female & 171 & 2.81 & .74 & Agree \\
\hline \multirow[t]{2}{*}{2} & \multirow{2}{*}{$\begin{array}{l}\text { Access to home ICT helps pupils to learn } \\
\text { how to move around the environment }\end{array}$} & Male & 146 & 3.12 & .42 & Agree \\
\hline & & Female & 171 & 2.89 & .49 & Agree \\
\hline \multirow[t]{2}{*}{3} & \multirow{2}{*}{$\begin{array}{l}\text { Access to home ICT helps pupils to learn } \\
\text { interpersonal behavior }\end{array}$} & Male & 146 & 3.49 & .50 & Agree \\
\hline & & Female & 171 & 3.81 & .38 & Agree \\
\hline \multirow[t]{2}{*}{4} & \multirow{2}{*}{$\begin{array}{l}\text { Access to home ICT helps pupils to learn } \\
\text { how to accept authority }\end{array}$} & Male & 146 & 3.24 & .43 & Agree \\
\hline & & Female & 171 & 2.99 & .49 & Agree \\
\hline \multirow[t]{2}{*}{5} & \multirow{2}{*}{$\begin{array}{l}\text { Access to home ICT helps pupils to learn } \\
\text { how to coping with conflict }\end{array}$} & Male & 146 & 3.74 & .43 & Agree \\
\hline & & \begin{tabular}{|l|} 
Female \\
\end{tabular} & 171 & 3.38 & .48 & Agree \\
\hline \multirow[t]{2}{*}{6} & \multirow{2}{*}{$\begin{array}{l}\text { Access to home ICT helps pupils to learn } \\
\text { how to gain attention }\end{array}$} & Male & 146 & 2.75 & .43 & Agree \\
\hline & & Female & 171 & 3.59 & .49 & Agree \\
\hline \multirow[t]{2}{*}{7} & \multirow{2}{*}{$\begin{array}{l}\text { Access to home ICT helps pupils to learn } \\
\text { how to help others }\end{array}$} & Male & 146 & 3.30 & .53 & Agree \\
\hline & & Female & 171 & 2.98 & 49 & Agree \\
\hline \multirow[t]{2}{*}{8} & \multirow{2}{*}{$\begin{array}{l}\text { Access to home ICT helps pupils to learn on } \\
\text { the task behavior }\end{array}$} & Male & 146 & 2.74 & .43 & Agree \\
\hline & & Female & 171 & 2.81 & 38 & Agree \\
\hline \multirow[t]{2}{*}{9} & \multirow{2}{*}{$\begin{array}{l}\text { Access to home ICT helps pupils to learn } \\
\text { how to organize play }\end{array}$} & Male & 146 & 2.75 & .43 & Agree \\
\hline & & Female & 171 & 2.89 & .49 & Agree \\
\hline \multirow[t]{2}{*}{10} & \multirow{2}{*}{$\begin{array}{l}\text { Access to home ICT helps pupils to learn } \\
\text { positive attitude towards others }\end{array}$} & Male & 146 & 3.30 & .43 & Agree \\
\hline & & Female & 171 & 2.40 & .49 & Agree \\
\hline \multirow[t]{2}{*}{11} & \multirow{2}{*}{$\begin{array}{l}\text { Access to home ICT helps pupils to learn } \\
\text { positive attitudes towards self }\end{array}$} & Male & 146 & 2.70 & 30 & Agree \\
\hline & & Female & 171 & 2.61 & .48 & Agree \\
\hline \multirow[t]{2}{*}{12} & \multirow{2}{*}{$\begin{array}{l}\text { Access to home ICT helps pupils to learn } \\
\text { responsible behavior }\end{array}$} & Male & 146 & 2.95 & .43 & Agree \\
\hline & & Female & 171 & 2.79 & \begin{tabular}{|l}
.49 \\
\end{tabular} & Agree \\
\hline \multirow[t]{2}{*}{13} & \multirow{2}{*}{$\begin{array}{l}\text { Access to home ICT helps pupils to learn } \\
\text { how to carryout individual work }\end{array}$} & Male & 146 & 3.10 & .71 & Agree \\
\hline & & Female & 171 & 2.90 & .49 & Agree \\
\hline \multirow[t]{2}{*}{14} & \multirow{2}{*}{$\begin{array}{l}\text { Access to home ICT helps pupils to learn } \\
\text { how to perform before others }\end{array}$} & Male & 146 & 2.75 & .83 & Agree \\
\hline & & Female & 171 & 3.10 & .34 & Agree \\
\hline 15 & Access to home ICT helps pupils to learn & Male & 146 & 3.25 & .43 & Agree \\
\hline
\end{tabular}




\begin{tabular}{|c|c|c|c|c|c|c|}
\hline & group activities & Female & 171 & 2.40 & .49 & Agree \\
\hline \multirow[t]{2}{*}{16} & \multirow{2}{*}{$\begin{array}{l}\text { Access to home ICT helps pupils to learr } \\
\text { how to follow directions }\end{array}$} & Male & 146 & 3.20 & .70 & Agree \\
\hline & & Female & 171 & 3.21 & .43 & Agree \\
\hline & \multirow[t]{2}{*}{ Overall Mean Impact } & Male & 146 & 48.25 & 2.51 & Agree \\
\hline & & Female & 171 & 47.22 & 2.36 & Agree \\
\hline
\end{tabular}

Table 2 shows the mean ratings of the pupils on the perceived impact of home ICT on their social skill development. The analysis shows that the mean ratings of both male and female pupils on the items are more than the 2.50 criterion mean. Thus, both male and female pupils agree to the statements of the items 1 to 16 as the perceived impact of home ICT on the social skill development of pupils. In other words, the pupils agree that home ICT has positive impact on their social skill development. However, the overall mean ratings of 48.25 and 47.22 indicate that male pupils had higher mean rating than their female counterparts. Besides, the overall standard deviations of 2.51 and 2.36 for the male and female pupils imply that they did not differ much in their individual ratings on the items.

Ho: There is no significant difference in the mean ratings of male and female pupils on the perceived impact of home ICT on their social skill development.

Table 3: t-test analysis of the difference in the mean ratings of male and female pupils on the perceived impact of home ICT on their social skill development

\begin{tabular}{||l|l|l|l|l|l|l|l|}
\hline Gender & \multicolumn{1}{|c|}{$\mathbf{N}$} & \multicolumn{1}{|c|}{ Mean } & Std. Deviation & df & t & Sig. & Decision \\
\hline Male & 146 & 48.2534 & 2.51290 & 315 & 1.327 & .087 & NS \\
\hline Female & 171 & 45.2281 & 1.16847 & & & & \\
\hline
\end{tabular}

NS $=$ Not Significant

Table 3 shows that there is no significant difference in the mean ratings of male and female pupils on the perceived impact of home ICT on their social skill development, $t(315)=1.327, p=0.087$. Thus, the null hypothesis was not rejected since the probability value of 0.087 is greater than the 0.05 level of significance.

\section{DISCUSSIONS}

The result of the study revealed that majority of the pupils do not have access to ICT in their homes. This agrees with the stand of UKessays (2018), who stated that majority of Nigerians live in remote and rural areas which lack social amenities and infrastructural development to support ICT facilities and that the population therein live in abject poverty. For this reason, the pupils do not access ICT at home and even in the school. Contrary to this, Tella (2011) who stated that there is the availability of home computers ICT in most homes. Furthermore, the study revealed that access to home ICT is helpful and impacts positively on pupils' social skill development. Ortiz, Green and Lim (2011) found that parents place a high value on computer usage and see it as vital to job success and academic achievement. This finding is in line with Olowe, and Kulelu (2014) who discovered that ICT contributes positively in all round development of the child including social skill development. The impression the pupils have is that ICT aids them in their social skill development. Several other studies have proved the effect of ICT on cognitive development of learners (Onah et al., 2020; Ugwuanyi et al., 2019a, 2019b; Ugwuanyi et al., 2020a, 2020b, 2020c, 2020d; Ugwuanyi \& Okeke, 2020; Ejimuonye et al., 2020a, 2020b. The 
result of the study is in line with the findings of Tondeur et al (2011) who discovered that gender has no influence in the use of home computer and ICT. The finding also collaborated Naciri (2014) who stated that there seems to be no significant difference on gender in terms of access, use and impact of home ICT bur there is in terms of attitude and pattern of usage.

\section{CONCLUSIONS}

From the findings made, it was discovered that a good number of pupils do not have access to home ICT facilities. This could point to the fact that home ICT may not be in their homes. The absence of home ICT leads to the inability of the pupils to access home ICT thereby inhibiting the pupils' development especially social skill development. Perception influences people's behaviour generally, since the pupils perceive that home ICT could impact positively in their social skill development, the absence of home ICT may lead to frustration and poor social skill development. The implication of the findings is that the more the pupils have access to home ICT the more they may improve their social skill development and be better equipped to live in the society. Therefore, access to home ICT will help pupils improve their social skills development which in turn may improve their cognitive, physical and emotional development and hence enhancing their self-esteem and social competence.

\section{RECOMMENDATIONS}

Based on the findings of the study, the following recommendations are made:

Local government education authority should make provisions through stakeholders for easy access of home ICT to enable pupils develop their social skills adequately.

Parents should endaviour to provide home ICT in the home and allow the pupils access to such home ICTs.

The ministry of education through the local government education authority, should supply subsidized home computers equipped with ICT facilities to make them affordable to parents.

\section{ACKNOWLEDGMENTS}

The researchers are grateful to all the participants used for the conduct of this research for their wonderful cooperation throughout the course of the research. The researchers also appreciate Dr Anthonia N. Ngwoke for serving as a contact person for any information concerning the conduct of this research.

\section{REFERENCES}

1. Alberta, E. (2019). Information and communicatons technology (ICT) Retrived from; https://www.techopedia.com/definition/24152/information-and-communications-technology-ict

2. Bakola, L. N., Rizos, N.D. \& Drigas, A. (2019). ICTs for emotional and social skill development for children with ADHD and ASD Co-existence. International Journal of emerging technologies in learning (iJet) I4(05), 122-131.

3. Bedford Borough Council (2018). Who is a parent? Retrieved from; https://www.bedford.gov.uk/education_and_learning/education_welfare_service/school_attendance_and_the_law/who_is_a_p arent.aspx

4. Chukwu, J.O. (2011). Early childhood education and national development. International Journal of Educational Research.11 (1) $33-38$ 
5. Collins, C. (2020). Definition of primary school. Retrieved form; https://www.collinsdictionary.com/dictionary/english/primary-school.

6. Cullinane, C. \& Montacute, R. (2017). Improving essential life skills for young people. Retrieved from; https://www.suttontrust.com/wp-content/uploads/2017/10/Life Lessons Report_FINAL.pdf

7. Education and Training Directorate. (2015). Primary schools (public).Retrieved from: http:// www.det.act.gov.au/school education/directory of schools/primary schools act government.

a. $\quad$ Educational Management 6 (2), 56-64.

8. Ejimonye, J.C., Onuoha, J.C., Ugwuanyi, C.S., Eneogu, N.D., Ugwuanyi, B.E \& Ogbuehu, S.N (2020a). Effectiveness of TwoDimensional Animation Technique in Enhancing Students' Motivation in Quantitative Economics Concepts. International Journal of Future Generation Communication and Networking (IJFGCN), 13(1):27-38.

9. Ejimonye, J.C., Ugwuanyi, C.S., Okeke, C.I.O., \& Nwoye, M.N. (2020b). Two-Dimensional Animation and Students' Achievement in Mathematical Economics: Implications for Science Teaching. International Journal of Engineering Research and Technology, 13(6), 1220-1230

10. Federal Republic of Nigeria, (2013) National policy on education (6 $6^{\text {th }}$ Edition). Lagos, NERDC Press.

11. Joseph, R. (2017). What is the difference between a home computer, a personal computer, and a desktop computer? Retrieved from; $\quad$ https://www.quora.com/What-is-the-difference-between-a-home-computer-a-personal-computer-and-a-desktopcomputer

12. Mazarin, J. (2020). What are social skills in children? -development, definition \& teaching techniques. Retrieved from; https://www.study.com/academy/lesson/what-are-social-skills-in-children-development-definition-teaching-techniques.html

13. Naciri, H. (2014). Gender discrepancies in the use of ICT in higher education. Retrieved from; https://www.conference.pixelonline.net/ICT4LL/files/ict4ll/ed0009/FP/3066-ICL1944-FP-ICT4LL9.pdf

14. Nikolopoulou, K. \& Gialamas, V. (2010). Young children's access to and use of ICT at home. Reteived from; https://www.researchgate.net/publication/46122880_Young_children\%27s_access_to_and_use_of_ICT_at_home

15. Nyqvist, K.H. \& Engvall, G. (2009). Parents as their infant's primary caregivers in a neonatal intensive care unit.Journal of Pediatric Nursing, US National Library of Medicine, National Institute of Health, 84 (2):153-63.

16. Okenyi, E.C., Ugwuanyi, C.S. \& Ugwu, G.C. (2018). Appraisal of the status of instructional materials, water and environmental sanitation in early childcare centres in public primary schools in Udenu Local Government Education Authority. Journal of Research and Practice in Childhood Education 4 P.1-13.

17. Olowe, P. K. \& Kutelu, B. O. (2014). Percieved importance of ICT in preparing early childhood education teachers for the new generation children. International Journal of research in education (IJERE). 3(2), 119-124

18. Onah, E.N., Ugwuanyi, C.S., Okeke, C.I.O., Nworgu, B.G., Agwagah, U.V.N., Ugwuanyi, C.C., Obe, P.I., Nwoye, M. N., \& Okeke, A.O. (2020). Evaluation of the Impact of Computer-Assisted Instruction on Mathematics and Physics Students' Achievement: Implication for Industrial Technical Education. International Journal of Engineering Research and Technology, 13(7): 1786-1794. http://irphouse.com/ijert20/ijertv13n7 35.pdf.

19. Onuselogu, A. P. (2007). Extent of resource adequacy for the implementation of Universal Basic Education (UBE) in public schools in Anambra State. Nigerian Journal of Educational Management, 6(2), 56-64. 
20. Ortiz, R. W., Green, T\& Lim, H.J (2011). Home Computer Use: Exploring Parent Perceptions of the Importance of Current Technology. Urban Education, 46(2):202- 215. sagepub.com/journalsPermissions.nav. DOI: $10.1177 / 0042085910377433$

21. Raji, I.A. (2004). Provision of basic education in a federal state: A search for an efficient path for Nigeria. In J.B Babalola (eds) Management of primary and secondary education in Nigeria. NAEAP Publication, Ibadan, PP 427-438.

22. Ratheeswari, K. (2018). Information technology in Education. Retrieved from; https://www.researchgate.net/publication/325087961_Information_Communication_Technology_in_Education

23. Reflection Sciences (2017). What is social development in early childhood? https://www.reflectionsciences.coom/earlychildhood-social-development/

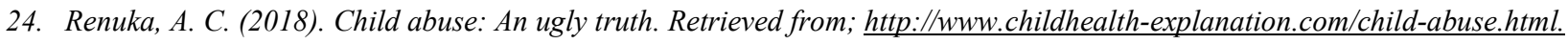

25. Ryan, C. \& Lewis, J. (2017). Conputer and internet use in the United States. Retrieved from; https://www.census.gov/library/publications/2017/acs/acs-37.html

26. SkillsYouNeed.com (2020). What are social skills. Retrieved form; https://www.skillsyouneed.com/ips/social-skills.html

27. Social Mettle, (2018). Agents of Socialization. Retrieved from; https://www.socialmettle.Com/agents-of-socialization.

28. Subrahmanyam, K., Kraut, R.E., Greenfield, P.M. \& Gross, E.F. (2000). The impact of home computer use on children's activities and development. Retrieved from; file:///C:/Users/DELL/Desktop/Home\%20computer\%20use.pdf

29. Tagarira, A. T. (2017). Benefits of ICT in early childhood education. Retrived from; https://www.ukessays.com/essays/childcare/benefits-ict-childhood-education-6369.php

30. Tella, A. (2011). Availability and use of ICT in South-Western Nigeria. International Multidisciplinary Journal, Ethiopia. 5 (5), 315-331.

31. Tondeur, J., Sinnaeve I., van Houtte, M., \& van Braak, J. (2011). ICT as cultural capital: Effects of socioeconomic status on the ICT profile of young people. New Media \& Society, 13(1), 151-168.

32. Ugwuanyi, C. S., Okeke, C. I. O., Nnamani, P. A., Obochi, E. C. \& Obasi, C. C. (2020a). Relative effect of animated and nonanimated powerpoint presentations on physics students' achievement. Cypriot Journal of Educational Science. 15(2), $282-291$. https://doi.org/10.18844/cjes.v15i2.4647

33. Ugwuanyi, C. S., Okeke, C.I.O. \& Asomugha, C.G., (2020). Prediction of learners' mathematics performance by their emotional intelligence, self-esteem, and self-efficacy. Cypriot Journal of Educational Science. 15(3), $492-501$. http://dx.doi.org/10.18844/cjes.v\%vi\%i.4916

34. Ugwuanyi, C.S., \& Okeke, C.I.O. (2020). Enhancing University Students 'Achievement in Physics using Computer-Assisted Instruction. International Journal of Higher Education 9(5), 115-124. https://doi.org/10.5430/ijhe.v9n5p115

35. Ugwuanyi, C.S., Nduji, C.C., Elejere, U.C., \& Omeke, N.E. (2020c). Effect of Flipped Classroom and Think Pair Share Strategy on Achievement and Retention Among Senior Secondary School Physics Students. International Journal of Sciences: $\begin{array}{llll}\text { Basic and } \quad \text { Applied } & \text { (IJSBAR), }\end{array}$ https://www.gssrr.org/index.php/JournalOfBasicAndApplied/article/view/11250/5681

36. Ugwuanyi, C.S., Nduji, C.C., Gana, C.S., Nwajiuba, C.A., Ene, C.U., Okeke, A.O., Eseadi, C., Okeke, C.F. (2019b). Effectiveness of flipped classroom instructional technology model in enhancing students' achievement in physics. International Journal of u- and e-Service, Science and Technology, 12(4): 37-46. 
37. Ugwuanyi, C.S., Okenyi, E.C., Ezema, V., \& Amoke, C. (2020d). Effect of digital game-based learning on achievement of primary school pupils in sciences in Enugu State, Nigeria. Journal of Educational Research on Children, Parents \& Teachers, $1(1), 35-44$.

38. Ugwuanyi, C.S., Ugwuanyi, C.C., Ezenwa-Nebife, D.C., Gana, C., Ene, C., Oguguo, B.C., Ikeh, F.E., Okeke, A.O., Nwoye, M.N., Obi, C.N., Anyaegbu, C. \& Agah, J.J. (2019b). Assessment of the efficacy of information and communication technology tool on achievement of students in physics and mathematics: A case of repeated measures. Journal of Engineering and Applied Sciences, 14(13), 4541-4546.

39. UKessays (2018). Barriers to ICT in Nigeria schools - Research. Retrieved from; https://www.ukessays.com/essays/education/barriers-to-ict-usage-in-nigeria-education-essay.php

40. Wartella, E., Vandewater, E. \& Rideout, V. (2006). Introduction: electronic media use in the lives of infants, toddlers and preshcoolers. American Behaviorial Scientist, 48(5), 204-223 